DEEP SEA DRILLING

Three Year Exiension

by our Washington Correspondent

THE National Science Foundation's highly successful Deep Sea Drilling Project (DSDP) has been given a new lease of life. The foundation announced last week that the DSDP drilling ship, Glomar Challenger, will continue drilling into ocean floors until August 1975, and that it will take samples from previously uncharted areas. The DSDP was originally scheduled to finish later this year. The extension of the project will enable another 19 voyages to be made, at a cost of $\$ 33$ million, bringing the total cost of the project up to $\$ 68$ million.

The decision is a massive vote of confidence in a project which has already been instrumental in shaping or confirming theories of geophysics which have in the past few years revolutionized concepts about the history of the Earth. Since its first voyage in 1968, the Glomar Challenger has drilled in 220 separate locations, sending back a wealth of information about the constitution and age of ocean floors. Among other things, this information has tended to confirm the theory of sea floor spreading, since it has demonstrated that the age of the ocean floor increases from the area of crustal regeneration at the mid-ocean ridges to the deep sea trenches where it is destroyed.

The extension of the Deep Sea Drilling Project will take the Glomar Challenger into Arctic and Antarctic waters for the first time, and it will also take samples from the Red Sea floor, where the enigmatic areas of hot brine and mineral sediments will be studied. Also planned is a drill which will go up to three thousand feet into the rock beneath the sediments of the ocean. Previous drills have only gone a hundred feet or so beneath the sediments.

The voyage into the Red Sea should help to pin down the rate of spread of the sea floor in that area, which in turn will give the speed at which Africa and Arabia are moving apart. This area is particularly interesting scientifically, since the Red Sea is one of the youngest oceans in the world, but it is also interesting because there are layers of brine at the base of the Red Sea which are much hotter than the surface waters. One theory is that these patches of brine are rich in minerals derived from geological process rather than by recirculation, and there has been considerable interest in commercial exploitation of the minerals in the brine and in the bottom sediments. For one thing, since the Red Sea is relatively shallow, mineral deposits are fairly easily accessible.
As for the proposed drillings in the Arctic and Antarctic, one likely consequence is that the date at which Australia broke away from Gondwanalanda variable about which there has been considerable speculation and disagreement-may be better known, and another objective of the mission will be to probe the geology of the Antarctic.

Another part of the extended operation of the Glomar Challenger that has been greeted with enthusiasm by geophysicists is the proposal to drill more deeply than before into the rock underlying ocean sediments. Such an operation has been made possible by a technique which allows a previously drilled hole to be re-entered by a new drilling bit. This technique, which is accomplished by a sonar device, allows worn bits to be replaced, and was first successfully carried out in late 1970.

\title{
Gesture for Educution
}

THE House of Representatives Committee on Science and Astronautics has again urged the National Science Foundation to spend more money on graduate student support, science education and institutional support. In what is becoming almost an annual ritual, the committee, on the recommendation of its subcommittee on science, research and development, two weeks ago reported out a bill which revamps the NSF's budget request, authorizing appropriations of $\$ 680.0$ million- $\$ 27.8$ million more than the foundation asked for-and taking money from other NSF activities to finance increases in its education support.

Last year, the committee transferred funds from the foundation's request for applied research to increase the budget for graduate student support and education, but this year the knife has been applied chiefly to the foundation's basic research programmes. In short, the committee has lopped $\$ 4.3$ million off the budget for scientific research project support and $\$ 2.2$ million off the request for national and special research programmes, but increased the appropriations request for institutional support by some $\$ 11$ million, for graduate support by $\$ 10.8$ million and for science education by some $\$ 13$ million. (The figures contained in the foundation's budget for 1973 include some money carried over from the present financial year.)

A staff member of the committee explained that the decision to take money away from the NSF's requests for basic science in no way represents disapproval of the programmes, but is simply a measure designed to increase the foundation's support of science education while keeping the overall budget increases to a minimum. The authorizations bill does not specify which programmes should be reduced, although it is recommending that $\$ 2$ million be chopped from the new technology incentives programme, and that the research and development assessment programme be reduced by $\$ 200,000$. One recommendation, which will be welcomed at least by astronomers, is that the committee has given its blessing to the Very Large Array system of antennas for radio astronomy.

As for the graduate student support programmes, the committee is recommending that the NSF's traineeship programme be reinstated on a rather limited basis. The Administration has been attempting to kill the traineeship programme for the past two years, chiefly because of the present unemployment situation among PhDs, but each year the Science and Astronautics Committee has increased the budget request. The chief result has in the past been that the Office of Management and Budget impounds the increases voted by Congress, and the foundation winds up that much the poorer. This year, however, the committee is suggesting that the traineeship programme be reinstated at least for those areas such as environmental sciences where manpower is likely to be in short supply.

Frustrated in the past in its endeavours to increase support for science education and graduate students, the committee this year has included in its authorizations bill some recommended changes in the National Science Foundation Act. Essentially these changes, if agreed by Congress, would raise education to the same level of importance as support of basic science in the NSF's activities. The changes, which were inserted in the authorizations bill by the full committee, would be a powerful expression of congressional support for science education and may possibly make the Office of Management and Budget, and the foundation itself, think twice before sanctioning any future cuts in the foundation's budget in this area.

The Science and Astronautics Committee is only one of four congressional committees concerned with the NSF's budget, and it essentially sets upper limits for appropriations. By far the most powerful of the four committeesthe House Appropriations Committee-has in the past, however, followed the Science Committee's lead in urging greater expenditure on science education. 